\title{
KETERKAITAN RESIKO KECELAKAAN TERHADAP KAPASITAS JALAN DI KALIANAK KOTA SURABAYA
}

\author{
Siti Nuurlaily Rukmana ${ }^{1)}$ dan Vicky Firnaningsih ${ }^{2}$ ) \\ 1,2 Program Studi Perencanaan Wilayah \& Kota, Universitas PGRI Adi Buana Surabaya \\ email: nuurlaily_rukmana@unipasby.ac.id, vfirnaningsih@gmail.com
}

\begin{abstract}
Abstrak
Tingginya aktifitas sisi jalan atau hambatan samping menyebabkan kapasitas jalan menurun. Jalan Kalianak Kota Surabaya. mempunyai daya tarik cukup besar karena merupakan kawasan pergudangan, permukiman, perdagangan dan jasa sehingga menimbulkan bangkitan dan tarikan. Hal ini tentunya berdampak pada tingkat kecelakaan. Tujuan Penelitian ini untuk mengidentifikasi kondisi kapasitas jalan, hambatan samping dan kecelakaan di Jalan Kalianak dan mengidentifikasi pengaruh hambatan samping terhadap kapasitas jalan dan resiko terjadinya kecelakaan. Metode penelitian yang digunakan adalah deskriptif kuantitatif dengan teknik analisis korelasi parsial. Hasil penelitian menunjukkan bahwa nilai kapasitas tertinggi pada segmen 5 sebesar 5689,80 smp/jam; sedangkan untuk tingkat pelayanan jalan pada setiap segmen yaitu sama di hari senin dan kamis berada pada kategori $C$ dan di hari minggu berada pada kategori B. Hambatan samping tergolong tinggi $(H)$ di jalan kalianak yaitu segmen 1 dan segmen 2 terjadi pada hari senin dan kamis sedangkan untuk hari minggu nilai hambatan samping tergolong L (rendah). Hasil uji korelasi parsial menyatakan pengaruh antara variabel hambatan samping $\left(X_{1}\right)$ dan kapasitas jalan $\left(X_{2}\right)$ dengan kecelakaan $(Y)$ sangat kuat dengan kontribusi hambatan samping (X1) dan Kapasitas Jalan $\left(X_{2}\right)$ sebesar $97 \%$ terhadap kejadian kecelakaan sedangkan 3\% kejadian kecelakaan di sebabkan oleh faktor lain seperti kelalaian pengemudi serta kondisi jalan yang rusak.
\end{abstract}

Kata Kunci : hambatan samping, Jalan Kalianak, kapasitas jalan, kecelakaan

\begin{abstract}
High activity on the side of the road or side frictions causes the declining of road capacity. Kalianak Street has considerable fascination because it has warehousing area, settlement, trade and services area that causes generation and attraction. Kalianak Street is the most vulnerable spot of accidents. The purpose of this research are to identify the conditions of road capacity, side frictions and accidents in Kalianak Street as well as to identify the effect of side frictions against road capacity and risk of accidents. This research method using descriptive quantitative with partial correlation analysis technique. The result in this research showed that the value of highest capacity is in segment 5 with 5689,80 pcu / hour; while for the level of the road service in each segment are equal on Monday and Thursday with category " $C$ ", otherwise the category " $B$ " occurs on Sunday. In addition, the high $(H)$ classification of side fricitions in the Kalianak Street is segment 1 and segment 2 that occurs on Monday and Thursday, while for Sunday the value of side frictions is low $(L)$. The result of partial correlation test showed the effect between the side frictions $\left(X_{1}\right)$ and the road capacity $\left(X_{2}\right)$ with the accidents $(Y)$ are very strong, as well as with the $97 \%$ contribution of side frictions $\left(X_{1}\right)$ and the Road Capacity $\left(X_{2}\right)$ to the accidents while the rest of $3 \%$ caused by another factors such as driver negligence and poor road conditions.
\end{abstract}

Keywords: accidents, Kalianak Street, road capacity, side frictions. 


\section{PENDAHULUAN}

Kecelakaan menjadi permasalahan serius di kota-kota besar seperti Kota Surabaya. Berdasarkan Undang-undang Nomor 22 Pasal 1 Tahun 2009 tentang Lalu Lintas dan Angkutan Jalan, mengungkapkan kecelakaan lalu lintas adalah suatu peristiwa di jalan yang tidak diduga dan tidak disengaja yang melibatkan kendaraan dengan atau tanpa pengguna jalan lain yang mengakibatkan korban manusia dan/atau kerugian harta benda (Anonim, 2009). Jumlah kecelakaan di
Surabaya pada tahun 2013 - 2015 rata-rata meningkat $2 \%$ per tahun (BPS, 2016).

Jalan Kalianak merupakan jalan arteri primer yang menghubungkan Kota Surabaya dengan Kabupaten Gresik yang memiliki panjang 2,3 $\mathrm{Km}$ dengan lebar $19 \mathrm{~m}$ terbagi menjadi 2 jalur 4 lajur tanpa median. Ruas jalan tersebut merupakan kawasan pergudangan, permukiman, perdagangan dan jasa menjadi daya tarik cukup besar, karena erat kaitannya dengan proses bongkar muat ekspor dan import (Gambar 1).

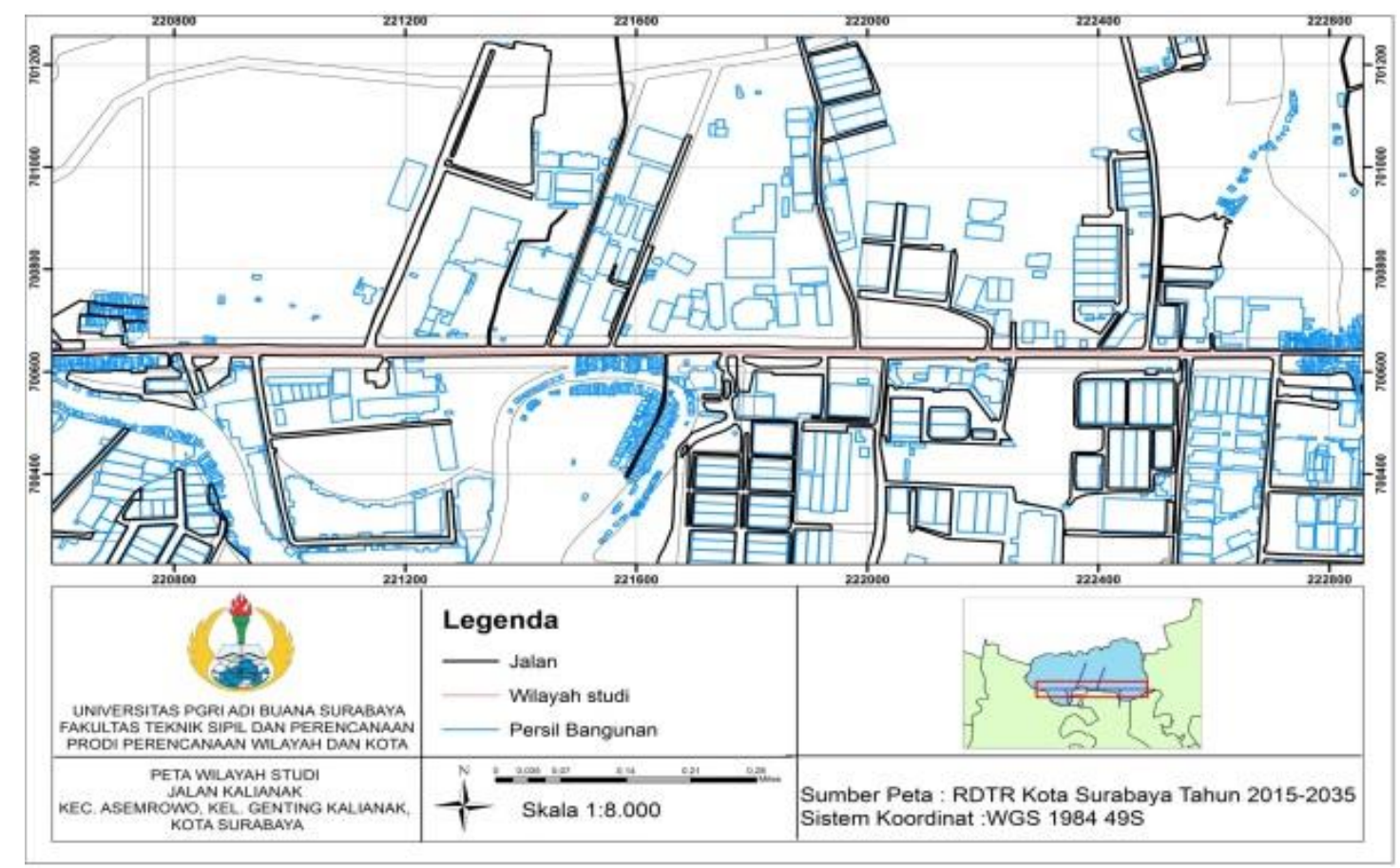

Gambar 1. Peta Wilayah Studi

Tingginya aktifitas sisi jalan atau hambatan samping cukup berpengaruh terhadap tingkat kinerja arus lalu lintas (Marunsenge dan Elisabeth, 2015) Aktivitas keluar masuk kendaraan dari lahan pergudangan mengakibatkan hambatan samping yang menimbulkan bangkitan dan tarikan di Jalan Kalianak. Untuk daerah titik rawan yang sering terjadi kecelakaan dalam kurun waktu 4 tahun (tahun 2006 - 2009) pada segmen I (Jalan Kalianak - Greges) dengan jumlah 92 kecelakaan dengan faktor utama yang menyebabkan terjadinya kecelakaan karena faktor manusia dengan nilai prosentase $48,04 \%$, disusul dengan faktor kondisi kendaraan dengan nilai prosentase 22,34 \% (Putra, 2011). Berdasarkan permasalahan tersebut maka perlu dilakukan penelitian mengenai pengaruh hambatan samping terhadap kapasitas jalan dan resiko terjadinya kecelakaan di Jalan Kalianak untuk 
mengidentifikasi kondisi karakteristik jalan Kalianak dan besar pengaruh yang ditimbulkan dari hambatan samping dan kapasitas jalan terhadap kecelakan

\section{METODE PENELITIAN}

Jenis penelitian pada penelitian ini adalah deskriptif kuantitatif dengan teknik analisis korelasi parsial. Korelasi Parsial (Partial Correlation) menurut (Sulistiyono dalam Telussa, 2013) korelasi parsial adalah suatu teknik statistika yang digunakan untuk mempelajari hubungan murni antara sebuah variabel bebas (X1) dengan variabel terikat $(\mathrm{Y})$ dengan mengendalikan atau mengontrol variabel-variabel bebas yang lain (X2). menggunakan software SPSS 20 sedangkan sasaran ruang lingkup penelitian ini adalah Jalan Kalianak.

Pengumpulan data pada penelitian ini menggunakan metode observasi atau survei langsung ke lokasi penelitian. Observasi pengambilan data dilakukan pada weekday yang diwakili pada hari Senin dan Kamis sedangkan untuk pengamatan weekend dilakukan pada hari Minggu. Sedangkan untuk waktu dibagi 3 sesi yaitu pagi, sore, dan malam. Observasi pada pagi hari dilakukan pada pukul 06.00 - 08.00 WIB sedangkan observasi siang dilakukan pada pukul 11.00 13.00 WIB dan untuk sore hari dilakukan pada pukul $16.00-18.00$ WIB. Titik survey observasi pada penelitian yang akan dilakukan terbagi menjadi 5 segmen berdasarkan persimpangan keluar masuknya kendaraan. Jalan Kalianak memiliki panjang 2,3 km sedangkan observasi yang dilakukan dibagi setiap segmen sebagai berikut :

- Segmen 1, sepanjang 400 meter

- Segmen 2, sepanjang 500 meter

- Segmen 3, sepanjang 420 meter

- Segmen 4, sepanjang 450 meter

- Segmen 5, sepanjang 500 meter

\section{HASIL DAN PEMBAHASAN}

A. Karakteristik Kondisi Jalan Kalianak Penelitian ini berlokasi di Jalan Kalianak dibagi menjadi 5 segmen. Berikut pembagiannya Segmen 1, Segmen ini didominasi oleh kawasan permukiman, dan pergudangan yaitu : Mentari Line. Segmen 2, Di Kawasan segmen ini berupa Pergudangan yaitu Indra Jaya Swastika dan Bengkel bubut ABC. Segmen 3, Disegmen berupa pergudangan umum yaitu Panadia dan kantor Samudera Indonesia. Segmen 4 berupa depo container yaitu :Primamas Segara Unggul, Warehouse dan Expedisi S.A cepat. Segmen 5 berupa perdagangan dan jasa yaitu Kalianak Permai dan Permukiman. 


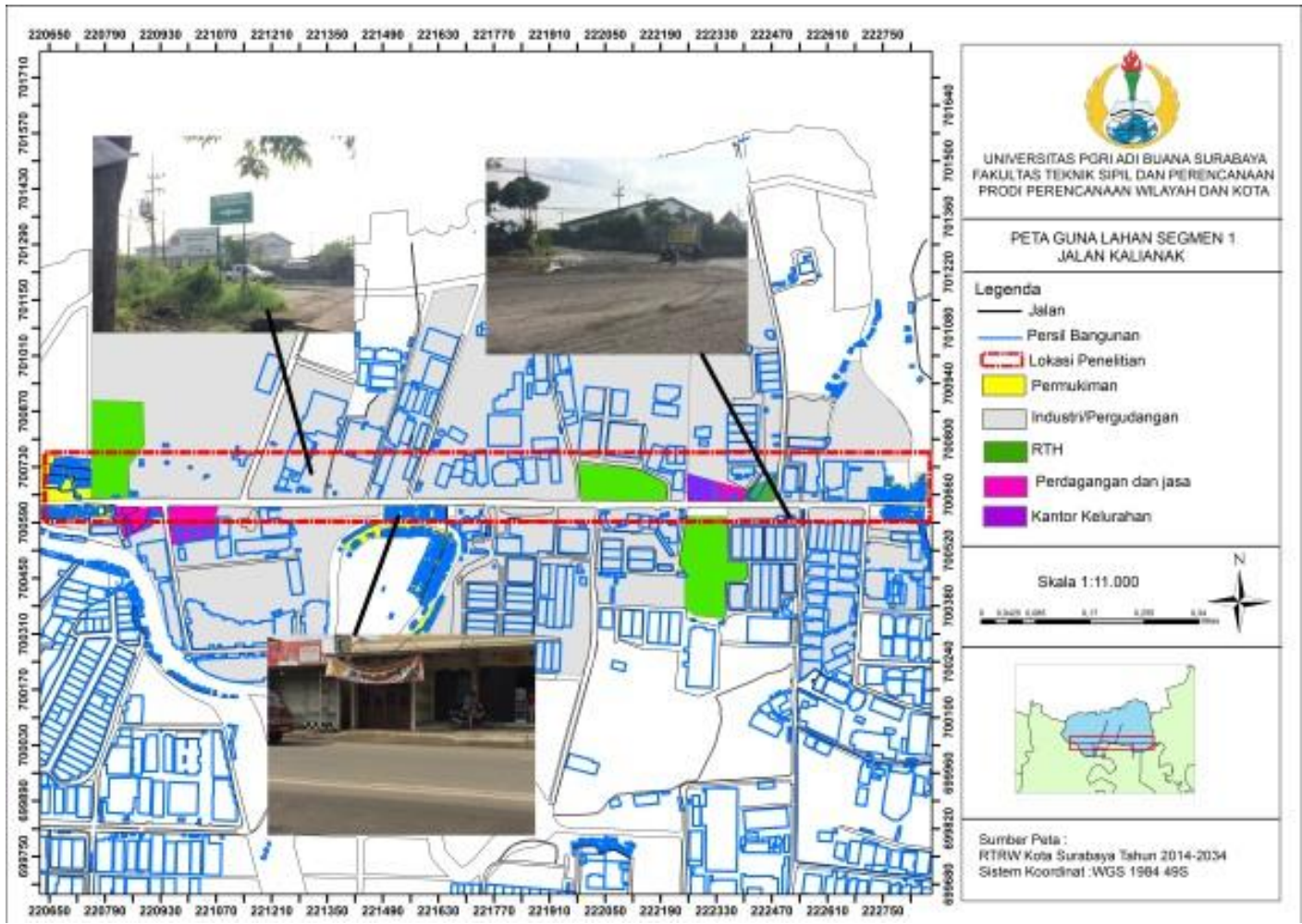

Gambar 2. Peta Pembagian Segmen Jalan Kalianak

\section{1) Kapasitas Jalan}

Jalan Kalianak merupakan arteri primer penghubung antara Kota Surabaya dan Kabupaten Gresik. Panjang jalan Kalianak yaitu 2,3 Km dengan klasifikasi jalan 4/2 UD. Dalam penelitian ini akan di bagi dalam 5 segmen, perhitungan kapasitas jalan dengan menggunakan rumus MKJI 1997 sebagai berikut

$$
\mathrm{C}=\mathrm{Co} \times \mathrm{FCw} \times \text { FCsp } \times \text { FCsf } \times \text { FCcs }
$$

Hasil perhitungan dapat dilihat pada tabel 1 .

Tabel 1

Kapasitas Jalan Kalianak Persegmen

\begin{tabular}{ccccccc}
\hline Segmen & Co & Fcw & FCsp & $\begin{array}{c}\text { FCsf } \\
(\text { Kerb })\end{array}$ & FCcs & C \\
\hline Segmen 1 & 6000 & 1,09 & 0,97 & 0,87 & 1,00 & 5519,11 \\
Segmen 2 & 6000 & 1,09 & 0,985 & 0,87 & 1,00 & 5604,45 \\
Segmen 3 & 6000 & 1,09 & 0,97 & 0,87 & 1,00 & 5519,11 \\
Segmen 4 & 6000 & 1,09 & 0,985 & 0,87 & 1,00 & 5604,45 \\
Segmen 5 & 6000 & 1,09 & 1,00 & 0,87 & 1,00 & 5689,80 \\
\hline
\end{tabular}

Sumber:Hasil Analisis, 2017 
Dari tabel 1 menunjukkan kapasitas jalan setiap segmen di Jalan Kalianak berbeda - beda dengan nilai kapasitas tertinggi yaitu terletak pada segmen 5 dengan nilai kapasitas jalan 5689,80 smp/jam hal ini dikarenakan pada segmen 5 lebar jalur lebih besar dari segmen lainnya.

\section{2) Volume Kendaraan}

Hasil analisa volume kendaraan selama 2 minggu yang dilaksanakan pada hari senin, kamis, dan minggu. Dapat dilihat pada tabel 2 dan 3

Tabel 2

Hasil Analisis Volume Kendaran Persegmen Minggu Pertama

\begin{tabular}{|c|c|c|c|c|c|c|c|c|c|c|c|c|}
\hline \multirow{4}{*}{$\underset{n}{\text { Segme }}$} & \multicolumn{12}{|c|}{ Ming gu Pertama } \\
\hline & \multicolumn{3}{|c|}{$\begin{array}{c}\text { Arah Gresik } \\
\text { Surabaya }\end{array}$} & \multicolumn{3}{|c|}{$\begin{array}{c}\text { Arah Surabaya - } \\
\text { Gresik }\end{array}$} & \multicolumn{3}{|c|}{$\begin{array}{c}\text { Arah Gresik } \\
\text { Surabaya }\end{array}$} & \multicolumn{3}{|c|}{$\begin{array}{c}\text { Arah Surabaya - } \\
\text { Gresik }\end{array}$} \\
\hline & \multicolumn{6}{|c|}{ Weekday } & \multicolumn{6}{|c|}{ Weekend } \\
\hline & SMP & DS & LOS & SMP & DS & LOS & SMP & DS & LOS & SMP & DS & LOS \\
\hline 1 & 3339 & 0,6 & $\mathrm{C}$ & 3090 & 0,56 & $\mathrm{C}$ & 1602 & 0,29 & $\mathrm{~B}$ & 1864 & 0,34 & $\mathrm{~B}$ \\
\hline 2 & 2965 & 0,53 & $\mathrm{C}$ & 3053 & 0,54 & $\mathrm{C}$ & 1809 & 0,32 & B & 1926 & 0,34 & $\mathrm{~B}$ \\
\hline 3 & 2562 & 0,46 & $\mathrm{C}$ & 2795 & 0,5 & $\mathrm{C}$ & 1815 & 0,33 & B & 2043 & 0,37 & $\mathrm{~B}$ \\
\hline 4 & 2669 & 47 & $\mathrm{C}$ & 2660 & 0,47 & $\mathrm{C}$ & 2140 & 0,38 & B & 2158 & 0,39 & $\mathrm{~B}$ \\
\hline 5 & 2735 & 0,48 & $\mathrm{C}$ & 2433 & 0,42 & $\mathrm{C}$ & 2176 & 0,38 & B & 1980 & 0,35 & B \\
\hline
\end{tabular}

Sumber: Hasil Analisis, 2018

Tabel 3

Hasil Analisis Volume Kendaran Persegmen Minggu Pertama

\begin{tabular}{|c|c|c|c|c|c|c|c|c|c|c|c|c|}
\hline \multirow{4}{*}{$\begin{array}{l}\text { Segme } \\
\mathrm{n}\end{array}$} & \multicolumn{12}{|c|}{ Minggu Kedua } \\
\hline & \multicolumn{3}{|c|}{$\begin{array}{l}\text { Arah Gresik - } \\
\text { Surabaya }\end{array}$} & \multicolumn{3}{|c|}{$\begin{array}{c}\text { Arah Surabaya - } \\
\text { Gresik }\end{array}$} & \multicolumn{3}{|c|}{$\begin{array}{c}\text { Arah Gresik - } \\
\text { Surabaya }\end{array}$} & \multicolumn{3}{|c|}{$\begin{array}{c}\text { Arah Surabaya - } \\
\text { Gresik }\end{array}$} \\
\hline & \multicolumn{6}{|c|}{ Weekday } & \multicolumn{6}{|c|}{ Weekend } \\
\hline & $\begin{array}{c}\mathrm{SM} \\
\mathrm{P}\end{array}$ & DS & LOS & SMP & DS & LOS & SMP & DS & $\begin{array}{c}\mathrm{LO} \\
\mathrm{S}\end{array}$ & SMP & DS & LOS \\
\hline 1 & $\begin{array}{c}267 \\
8\end{array}$ & $\begin{array}{c}0,4 \\
8\end{array}$ & $\mathrm{C}$ & 3090 & 0,56 & $\mathrm{C}$ & 1717 & 0,31 & B & 1864 & 0,34 & B \\
\hline 2 & $\begin{array}{c}298 \\
6\end{array}$ & $\begin{array}{c}0,5 \\
3\end{array}$ & $\mathrm{C}$ & 3053 & 0,54 & $\mathrm{C}$ & 1766 & 0,32 & B & 1926 & 0,34 & B \\
\hline 3 & $\begin{array}{c}268 \\
6\end{array}$ & $\begin{array}{c}0,4 \\
8\end{array}$ & $\mathrm{C}$ & 2795 & 0,5 & $\mathrm{C}$ & 1921 & 0,35 & B & 2043 & 0,37 & B \\
\hline 4 & $\begin{array}{c}270 \\
5\end{array}$ & $\begin{array}{c}0,4 \\
8\end{array}$ & $\mathrm{C}$ & 2660 & 0,47 & $\mathrm{C}$ & 1992 & 0,36 & B & 2150 & 0,39 & B \\
\hline 5 & $\begin{array}{c}267 \\
1\end{array}$ & $\begin{array}{c}0,4 \\
7\end{array}$ & $\mathrm{C}$ & 2433 & 0,42 & C & 2053 & 0,36 & B & 1980 & 0,35 & B \\
\hline
\end{tabular}

Sumber: Hasil Analisis, 2018

Sesuai hasil perhitungan analisis volume lalu lintas harian rata-rata pada minggu pertama dan kedua yaitu sama dengan kategori LOS untuk weekday $\mathrm{C}$ sedangkan untuk weekend B. Hal ini dikarenakan untuk weekday merupakan hari 
aktif bekerja sehingga banyak kendaraan yang melintas di jalan Kalianak sedangkan untuk weekend merupakan hari libur sehingga jalanan sepi.

\section{3) Hambatan Sampling}

Data yang diambil dalam survei hambatan samping ini yaitu kendaraan yang berhenti dan parkir di bahu jalan, pejalan kaki (yang sejajar dan menyeberang jalan), kendaraan yang masuk dan keluar jalan serta kendaraan lambat. Setelah didapat data dari penelitian selanjutnya dikalikan dengan masing-masing faktor bobot hambatan samping menurut [6] MKJI 1997 yaitu (kendaraan parkir $=1$, kendaraan lambat $=0,4$, pejalan kaki $=0,5$ dan kendaraaan keluar + masuk $=0,7)$, maka hasil total hambatan samping dapat dilihat pada Tabel 4 .

Tabel 4

Analisis Hambatan Samping

\begin{tabular}{clcccc}
\hline \multirow{2}{*}{ Segmen } & \multicolumn{2}{c}{ Minggu Pertama } & \multicolumn{2}{c}{ Minggu Kedua } \\
& Hari & $\begin{array}{c}\text { Jumlah Kejadian } \\
(\text { SF/jam })\end{array}$ & $\begin{array}{c}\text { Kelas Hambatan } \\
\text { Samping (SCF) }\end{array}$ & $\begin{array}{c}\text { Jumlah } \\
\text { Kejadian } \\
\text { (SF/jam) }\end{array}$ & $\begin{array}{c}\text { Kelas Hambatan } \\
\text { Samping (SCF) }\end{array}$ \\
\hline \multirow{2}{*}{1} & Senin & 524 & H & 511 & H \\
& Kamis & 514 & H & 510 & H \\
& Minggu & 135 & L & 128 & L \\
2 & Senin & 516 & H & 503 & H \\
& Kamis & 507 & H & 515 & H \\
& Minggu & 138 & L & 137 & L \\
& Senin & 506 & H & 510 & H \\
& Kamis & 495 & M & 484 & M \\
& Minggu & 122 & L & 123 & L \\
& Senin & 326 & M & 340 & M \\
& Kamis & 343 & M & 326 & M \\
& Minggu & 113 & L & 116 & L \\
& Senin & 312 & M & 314 & M \\
& Kamis & 317 & M & 296 & M \\
& Minggu & 117 & L & 101 & L \\
\hline
\end{tabular}

Dari hasil analisis di dapatkan jumlah kejadian hambatan samping dengan nilai yang tergolong $\mathrm{H}$ (tinggi) yaitu pada segmen 1 dan segmen 2 yang terjadi pada hari senin dan kamis, dikarenakan kondisi eksisiting penggunaan lahan di segmen 1 dan 2 di digunakan sebagai permukiman, pergudangan atau industri mengakibatkan aktifitas sisi jalan yang tinggi. sedangkan untuk hari minggu nilai hambatan samping tergolong L (rendah) dikarenakan hari libur banyak pergudangan dan industri yang tutup. Berikut merupakan kondisi hambatan samping di segmen 1 dan 2 dapat dilihat pada gambar 3. 


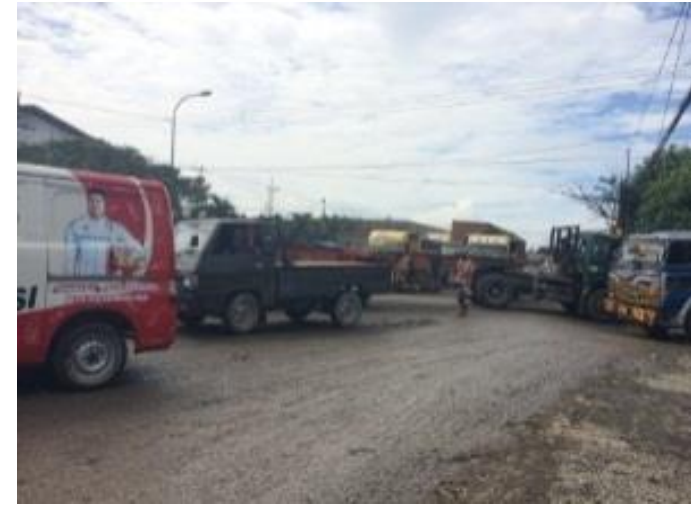

Gambar 3a. Kondisi Hambatan Samping Segmen 1

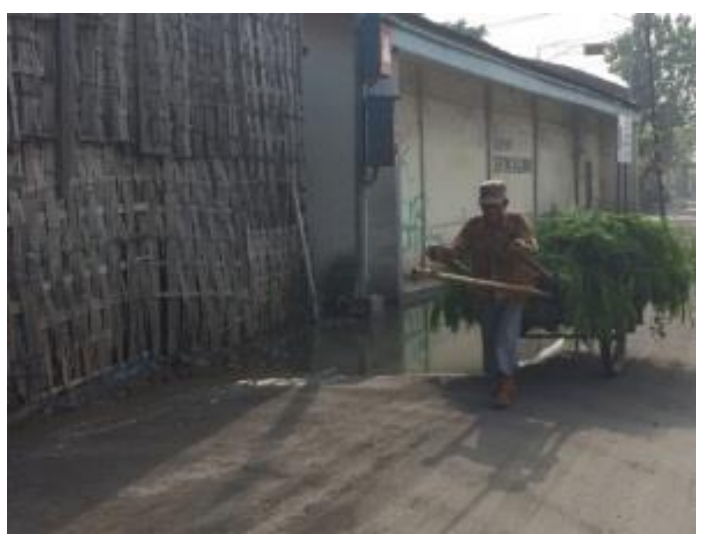

Gambar 3b. Kondisi Hambatan Samping

Segmen 1

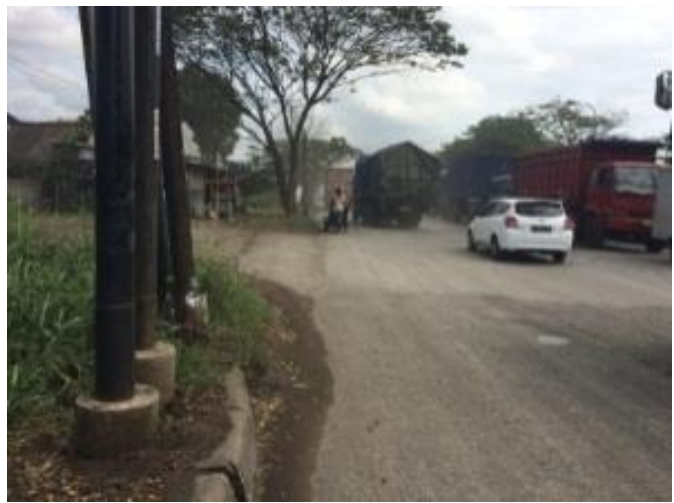

Gambar 3c. Kondisi Hambatan Samping Segmen

\section{4) Tingkat Kecelakaan}

Angka kecelakaan sebagai ukuran tingkat kecelakaan akan dianalisis pada jalan kalianak selama 5 tahun (2012-2016). Tingkat kecelakaan di jalan Kalianak setiap tahunnya mengalami peningkatan, peningkatan terbanyak pada tahun 2016 sebesar 32,6 jiwa/km perhitungan tingkat kecelakaan dapat dilihat pada tabel 5

Tabel 5

Analisis Tingkat Kecelakaan

\begin{tabular}{cccccc}
\hline $\begin{array}{c}\text { Tahu } \\
\mathrm{n}\end{array}$ & $\begin{array}{c}\text { Luka Berat } \\
\text { (LB) }\end{array}$ & $\begin{array}{c}\text { Jumlah Korban } \\
\text { Luka Ringan } \\
\text { (LR) }\end{array}$ & $\begin{array}{c}\text { Meninggal Dunia } \\
\text { (MD) }\end{array}$ & $\begin{array}{c}\text { Total Kecelakan Setiap } \\
\text { Tahun }\end{array}$ & $\begin{array}{c}\text { Hasil } \\
\text { Analsis } \\
(\text { Jiwa/K } \\
\text { m) }\end{array}$ \\
\hline 2012 & 2 & 16 & 6 & 24 & 10,43 \\
2013 & 3 & 27 & 10 & 40 & 17,39 \\
2014 & 0 & 21 & 19 & 40 & 17,39 \\
2015 & 0 & 37 & 9 & 46 & 20 \\
2016 & 7 & 38 & 30 & 75 & 32,6 \\
Total & 5 & 150 & 69 & 225 & 97,81 \\
\hline
\end{tabular}

Sumber: Hasil Analisis, 2018 
B. Pengaruh Hambatan Samping dan Kapasitas Terhadap Tingkat Kecelakaan

Analisis seberapa besar pengaruh dari hambatan samping dan kapasitas jalan terhadap resiko kecelakaan di jalan Kalianak dilakukan dengan menggunakan bantuan software SPSS 20 for windows

Variabel yang digunakan dalam penelitian ini yaitu 3 variabel berikut hambatan samping, kapasitas jalan dan angka kecelakaan. Variabel $\mathrm{Y}$ yaitu angka kecelakaan sedangakan untuk variabel X1 yaitu hambatan samping dan varibael X2 yaitu kapasitas jalan.

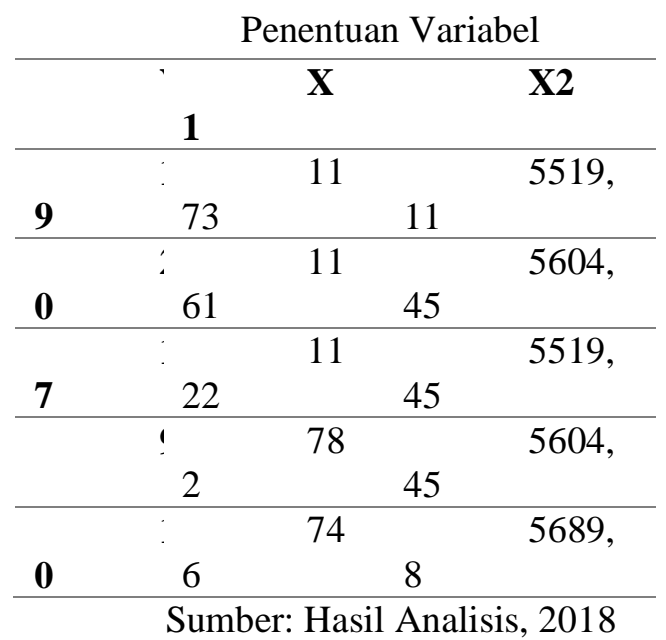

Tabel 6

Tabel 7

Hasil Uji Korelasi

Model Summary ${ }^{b}$

\begin{tabular}{|c|c|c|c|c|c|c|c|c|c|}
\hline \multirow[t]{2}{*}{ Model } & \multirow[t]{2}{*}{$\mathrm{R}$} & \multirow{2}{*}{$\begin{array}{c}\mathrm{R} \\
\text { Square }\end{array}$} & \multirow{2}{*}{$\begin{array}{l}\text { Adjusted } \\
\text { R Square }\end{array}$} & \multirow{2}{*}{$\begin{array}{l}\text { Std. Error } \\
\text { of the } \\
\text { Estimate }\end{array}$} & \multicolumn{5}{|c|}{ Change Statistics } \\
\hline & & & & & $\begin{array}{l}\text { R Square } \\
\text { Change }\end{array}$ & $\begin{array}{c}\mathrm{F} \\
\text { Change }\end{array}$ & df1 & df2 & $\begin{array}{l}\text { Sig. F } \\
\text { Change }\end{array}$ \\
\hline 1 &, $985^{\mathrm{a}}$ & ,970 & ,939 & 1,26939 &, 970 & 31,892 & 2 & 2 &, 030 \\
\hline
\end{tabular}

Sumber : Hasil Analisis, 2017

Berdasarkan hasil analisis maka dapat diketahui hasil hipotesis sebagai berikut:

$\mathrm{HO}=$ Tidak ada pengaruh antara variabel hambatan samping $\left(\mathrm{X}_{1}\right)$ dan kapasitas jalan $\left(\mathrm{X}_{2}\right)$ dengan kecelakaan $(\mathrm{Y})$

$\mathrm{H} 1=$ Ada pengaruh antara variabel hambatan samping $\left(\mathrm{X}_{1}\right)$ dan kapasitas jalan $\left(\mathrm{X}_{2}\right)$ dengan kecelakaan (Y)

Nilai koefisien korelasi (R square) sebesar 0,970 yang berarti menjadi korelasi sangat kuat antara variabel hambatan samping $\left(\mathrm{X}_{1}\right)$ dan kapasitas jalan $\left(\mathrm{X}_{2}\right)$ dengan kecelakaan $(\mathrm{Y})$.
Nilai dari signifikan yaitu sebesar 0,030 lebih kecil $(<)$ dari alfa $=0,05$ maka Ho ditolak, H1 diterima berarti ada pengaruh antara variabel variabel hambatan samping $\left(\mathrm{X}_{1}\right)$ dan kapasitas jalan $\left(\mathrm{X}_{2}\right)$ dengan kecelakaan (Y).

Sehingga dapat disimpulkan, ada pengaruh antara variabel hambatan samping samping $\left(\mathrm{X}_{1}\right)$ dan kapasitas jalan $\left(\mathrm{X}_{2}\right)$ dengan kecelakaan (Y) yaitu sangat kuat dan signifikan dengan kontribusi hambatan samping $\left(\mathrm{X}_{1}\right)$ dan kapasitas jalan $\left(\mathrm{X}_{2}\right)$ sebesar $97 \%$ terhadap kejadian kecelakaan sedangkan 3\% kejadian kecelakaan di sebabkan oleh faktor lain seperti kelalaian pengemudi serta kondisi jalan yang rusak. Hal ini selaras dengan (Yasa, 2011); 
(Rahmadi, 2011) bahwa hambatan samping memiliki pengarah yang sangat besar yang menyebabkan terganggunya arus lalu lintas sehingga terjadi kecelakaan lalu lintas.

\section{KESIMPULAN}

Kesimpulan yang dapat diuraikan pada penelitian ini yaitu:

1. Karakteristik kondisi Jalan Kalianak dapat dilihat dari kapasitas jalan tertinggi terletak di segmen 5 dengan nilai sebesar 5689,80 smp/jam dengan tingat pelayanan $\mathrm{C}$ (hari senin dan kamis) serta B (hari minggu). Selain itu, diketahui bahwa hambatan samping tergolong tinggi, sehingga sering terjadi kecelakaan.

2. Pengaruh hambatan samping dan kapasitas jalan terhadap risiko terjadinya kecelakaan dengan uji korelasi parsial pada SPSS 20 menunjukkan bahwa hambatan samping dan kapasitas jalan memiliki pengaruh yang kuat terhadap kecelakaan.

\section{REFERENSI}

Anonim. 2009. Undang-undang Nomor 22 Pasal 1 Tahun 2009 tentang Lalu Lintas dan Angkutan Jalan. Sekretariat Negara. Jakarta.

Badan Pusat Statistik Kota Surabaya, 2016. Statistik Indonesia Tahun 2016. Surabaya

Marunsenge, Gallant Sondakh, James Timboeleng dan Lintong Elisabeth. 2015. Pengaruh Hambatan Samping Terhadap Kinerja Pada Ruas Jalan
Panjaitan (Kelenteng Ban HingKiong) Dengan Metode MKJI 1997. Manado: Jurusan Teknik Sipil, Universitas Sam Ratulangi Manado

Putra, Agung Nugroho. 2011. Pemetaan Lokasi Rawan Kecelakaan Pada Ruas Jalan Kalianak- Romokalisari Dengan Menggunakan Sistem Informasi Geografis (SIG). Surabaya : Universitas Pembangunan Nasional "Veteran" Jawa Timur

Rahmadi, Septian. 2011, "Kecelakaan Lalu Lintas di Kecamatan Duren Sawit Jakarta Timur" Skripsi: Universitas Indonesia

Telussa, Ade Marlen, Elvinus Richard dan Zeth Arthur. 2013. Penerapan Analisis Korelasi Parsial Untuk Menentukan Hubungan Pelaksanaan Fungsi Manajemen Kepegawaian Dengan Efektivitas Kerja Pegawai (Studi Kasus Pada Badan Pendapatan, PengelolaAn Keungan dan Aset Daerah Provinsi Maluku). Maluku : Jurusan Matematika FMIPA, Universitas UNPATTI

Yasa, I Made Tapa, dan I Ketut Sutapa. Pengaruh Hambatan Samping Terhadap Kapasitas Ruas Jalan Cokroaminoto Denpasar (Studi Kasus Di Depan Sekolah Taman Mahatma Gandhi). Denpasar : Jurusan Teknik Sipil, Politeknik Negeri Bali 
WAHANA

Volume 71, Nomor 1, 1 Juni 2019
e-ISSN: 2654-4954, p-ISSN: 0853-4403 